\title{
PERLINDUNGAN HUKUM BAGI PIHAK PEMBELI DAN KREDITUR ATAS PEMBLOKIRAN SERTIFIKAT HAK MILIK DALAM PELAKSANAAN PENGIKATAN PERJANJIAN JUAL BELI TANAH
}

\section{Alit Nurfatah Prihadiansyah, Ariawan}

Fakultas Hukum Universitas Tarumanagara (UNTAR) Jakarta, Indonesia

Email: prihadiansyahalit@gmail.com, ariawang@fh.untar.ac.id

\begin{abstract}
Abstrak
Mengikat jual beli tanah dengan status Sertifikat Hak Milik merupakan tindakan hukum awal yang mendahului tindakan hukum jual beli tanah. Akta pengikatan jual beli tanah dalam praktiknya sering dilakukan dalam bentuk akta otentik yang dibuat di hadapan Notaris, sehingga Akta Pengikatan Jual Beli adalah akta otentik yang memiliki kekuatan bukti sempurna. Berdasarkan uraian tersebut, ditetapkan 2 (dua) formulasi permasalahan, yaitu: (1) apakah akta pengikatan penjualan dan akta kekuasaan penjualan yang telah dilakukan sebelum Notaris dapat diminta pembatalan oleh pemilik petok; dan (2) apa perlindungan hukum bagi pembeli Sertifikat Tanah Milik. Metode penelitian yang digunakan adalah penelitian yuridis normatif. Hasil penelitian ini adalah bahwa pembeli tanah yang telah disertifikasi yang telah terbukti membeli dengan Kekuatan Jual Beli Yang Mengikat, terutama sertifikat tersebut telah benar asalnya dan telah diterbitkan lebih dari 5 (lima) tahun tidak mengajukan klaim, maka klaim atau keberatan pihak yang dirugikan dengan penerbitan sertifikat tersebut dianggap batal.
\end{abstract}

Kata Kunci: perlindungan hukum; pemilik tanah; sertifikat

\section{Abstract}

Binding of land sale and purchase with the status of Property Rights Certificate is an early legal action that precedes the legal act of buying and selling land. Deed of binding on the sale and purchase of land in practice is often made in the form of an authentic deed made before a Notary Public, so the Deed of Binding of Sale and Purchase is an authentic deed that has the power of perfect proof. Based on the description, determined 2 (two) formulations of the problem, namely: (1) whether the deed of binding of sale and deed of power of sale that has been made before the Notary public can be requested cancellation by the owner of the petok; and (2) what is the legal protection for the buyer of the Land Certificate of Property. The type of research used is normative juridical research. The result of this research is that the buyer of land that has been certified that has been proven to purchase with the Binding Buy and Sell Power, especially the certificate has been true origin and has been issued more than 5 (five) years do not file a claim, then the claim or objection of the party harmed by the issuance of the certificate is considered void.

Keywords: legal protection; landowners; certificates

$\begin{array}{ll}\text { How to cite: } & \text { Prihadiansyah, Alit Nurfatah., Ariawan (2021) Perlindungan Hukum Bagi Pihak Pembeli Dan Kreditur Atas } \\ & \text { Pemblokiran Sertifikat Hak Milik Dalam Pelaksanaan Pengikatan Perjanjian Jual Beli Tanah. Syntax Literate: } \\ & \text { Jurnal Ilmiah Indonesia. 6(7). http://dx.doi.org/10.36418/syntax-literate.v6i7.3455 } \\ \text { E-ISSN: } & \text { 2548-1398 } \\ \text { Published by: } & \text { Ridwan Institute }\end{array}$




\section{Pendahuluan}

Undang-Undang Pokok Agraria (UUPA) No. 5 tahun 1960 dalam Pasal 5 menyebutkan bahwa hukum agraria yang berlaku atas bumi, dan ruang angkasa ialah hukum adat (Dilapanga, 2017). Berdasarkan hukum adat perjanjian jual beli tanah merupakan perjanjian yang bersifat tunai, terang dan riil. Tunai artinya bahwa dengan dilakukannya perbuatan hukum tersebut hak atas tanah yang bersangkutan beralih kepada penerima hak. Terang artinya Perbuatan hukum tersebut harus dilakukan dihadapan Pejabat Pembuat Akta Tanah (PPAT) yang bertugas membuat aktanya.Riil artinya bahwa akta yang ditandatangani para pihak menunjukkan secara nyata dan riil. Akta tersebut membuktikan bahwa benar telah dilakukan perbuatan hukum yang bersangkutan, karena perbuatan hukum yang dilakukan merupakan perbuatan hukum pemindahan hak (Harsono, 1999).

Jual beli tanah merupakan hal yang sering terjadi dalam kehidupan sehari-hari di masyarakat.Istilah jual beli disebutkan dalam Pasal 26 Undang-Undang Pokok Agraria (UUPA) yaitu yang menyangkut jual beli hak milikatas tanah. Pasal-pasal lainnya tidak ada kata yang menyebutkan jual-beli, tetapi hanya disebutkan sebagai dialihkan. Pengertian dialihkan menunjukan suatu perbuatan hukum yang disengaja untuk memindahkan hak atas tanah kepada pihak lain. Jadi, meskipun dalam Pasal hanya disebutkan dialihkan,termasuk salah satunya adalah perbuatan hukum pemindahan hak atas tanah karena jual beli (Sutedi, 2008).

Perkembangan penduduk yang semakin meningkat, membuat kebutuhan tanah juga menjadi semakin tinggi, dan untuk mendapatkan tanah sekarang ini juga bukanlah hal yang mudah ditengah tingginya kebutuhan akan tanah, salah satu perolehannya dengan cara melalui jual beli.

Berlakunya UUPA menjadi dasar bagi terbitnya Peraturan Pemerintah Nomor 24 tahun 1997 tentang Pendaftaran Tanah. Mengenai perbuatan hokum pemindahan hak atas tanah maka wajib didaftarkan dan dicatat di Kantor Pertanahan. Sesuai dengan Pasal 6 ayat (2) PP Nomor 24 tahun 1997 dalam melaksanakan pendaftaran tanah, Kepala Kantor Pertanahan dibantu oleh PPAT dan Pejabat lain yang ditugaskan untuk melaksanakan kegiatan-kegiatan tertentu menurut Peraturan Pemerintah ini dan peraturan perundang-undangan yang bersangkutan. Berdasarkan hal tersebut terbit pula Peraturan pemerintah Nomor 37 tahun 1998 tentang Pejabat Pembuat Akta Tanah sebagai tindak lanjut dari Peraturan Pemerintah Nomor 24 tahun 1997 tentang Pendaftaran Tanah. Pembentukan peraturan perundang-undangan terkait pendaftaran tanah adalah apabila ada orang maupun badan hukum yang hendak melakukan perbuatan hukum peralihan hak atas tanah maka harus dilakukan sebagaimana ditetapkan. Secara normatif yuridis peralihan hak atas tanah khususnya Jual Beli hanya dapat dilakukan apabila pembayaran telah lunas, dilakukan dihadapan Pejabat Pembuat Akta Tanah dengan menandatangani Akta Jual Beli yang kemudian didaftarkan di Kantor Pertanahan.

Keadaan tersebut berbeda dengan ketentuan tentang perjanjian jual beliyang diatur dalam Kitab Undang-Undang Hukum Perdata (KUHPerdata).Sesuai dengan Pasal 1458 
KUHPerdata yang menyatakan bahwa "Jual beli itu dianggap telah terjadi antara kedua belah pihak, seketika setelahnya orang-orang ini mencapai sepakat tentang kebendaan tersebut dan harganya, meskipun kebendaan itu belum diserahkan, maupun harganya belum dibayar" (Soeikromo, 2013). Atas dasar Pasal tersebut, terlihat bahwa perjanjian dianggap telah ada sejak tercapai kata sepakat, meskipun barang yang diperjanjikan belum diserahkan maupun harganya belum dibayar.

Di dalam prakteknya, sering terjadi ketika ada pihak penjual dan pihak pembeli yang akan melakukan jual beli tanah tidak seketika langsung dilakukan pendaftaran tanah atas nama pembeli meski telah dibayar lunas. Hal tersebut dapat dikarenakan adanya halangan-halangan administratif, misalnya sertipikat masih dalam Hak Tanggungan, Pihak Penjual maupun Pihak Pembeli belum mampu untuk membayar pajak-pajak yang timbul akibat jual beli,sertipikat masih dalam proses turun waris, sertipikat masih dalam proses pemecahan dan lain sebagainya, sehingga penandatanganan akta jual beli hak atas tanah belum dapat dilakukan di hadapan Pejabat Pembuat Akta Tanah (PPAT), dan Pejabat Pembuat Akta Tanah (PPAT) yang bersangkutan juga akan menolak untuk membuatkan akta jual belinya.

Bahwa untuk mengatasi hal tersebut, dengan tujuan perbuatan hokum dalam transaksi jual beli mendapat perlindungan hukum, dengan demikian dapat dihindari akibat hukum yang merugikan pihak-pihak yang bersangkutan,serta guna kelancaran tertib administrasi pertanahan, maka ditemukan suatu terobosan hukum oleh Notaris.Dalam praktiknya yang hingga kini masih dilakukan dengan dibuatkannya Perjanjian Pengikatan Jual Beli (PPJB) dihadapan Notaris.

R. Subekti dalam bukunya menyatakan perjanjian pengikatan jual beliadalah perjanjian antar pihak penjual dan pihak pembeli sebelum dilaksanakannya jual beli dikarenakan adanya unsur-unsur yang harus dipenuhi untuk jual beli tersebut antara lain adalah sertipikat hak atas tanah belum ada karena masih dalam proses, atau belum terjadinya pelunasan harga atau pajak-pajak yang dikenakan terhadap jual beli hak atas tanah belum dapat dibayar baik oleh penjual atau pembeli (R. Subekti, 2010).

Walaupun isinya sudah mengatur tentang jual beli tanah namun formatnya baru sebatas pengikatan jual beli yaitu suatu bentuk perjanjian yang merupakan atau dapat dikatakan sebagai perjanjian pendahuluan sebelum dilakukannya perjanjian jual beli.Perjanjian Pengikatan Jual Beli (PPJB) itusendiri sebenarnya belum diatur dalam perundang-undangan yang dinamakan perjanjian pengikatan jual beli (Supriadi, 2006).

Perjanjian Pengikatan Jual Beli sering digunakan sebelum dilakukannya pembuatan akta jual beli hak atas tanah dihadapan PPAT. Pada kenyataannya Perjanjian Pengikatan Jual Beli ini tidak pernah diatur dalam peraturan perundang-undangan yang berkaitan dengan hak atas tanah, sehingga hal ini menimbulkan pertanyaan mengenai kekuatan Perjanjian Pengikatan Jual Beli terhadap sengketa hak atas tanah yang diikuti pemblokiran sertipikat di Kantor Pertanahan.

Seperti halnya perjanjian jual beli tanah dan bangunan yang terjadi antara Lasmini selaku penjual dan Sudiyana selaku pembeli yang dituangkan dalam Akta Pengikatan Jual Beli No. 04 yang dikeluarkan oleh Notaris Woedjoed Wiradi, SH. M.KN pada 
tanggal 11 November 2014, atas sebidang tanah dan bangunan milik Lasmini yang beralamat di Perumahan Wahana Pondok Gede Blok K.1 No. 1 RT 00 RW 007 Kelurahan Jatiranggon, Kecamatan Jatisampurna, Kota Bekasi, Propinsi Jawa Barat dengan Sertipikat Guna Bangunan Nomor 1661 Surat Ukur Nomor 2063/Jatiranggon atas nama Fery Zanwar, Ferdy Zanwar, Lasmini. Dalam Akta tersebut dijelaskan bahwa Sudiyana membeli sebidang tanah dan bangunan dengan harga sebesar Rp. 400.000.000,00 (empat ratus juta rupiah) dengan sistem pembayaran uang muka (tanda jadi) sebesar Rp. 50.000.000,00 (lima puluh juta rupiah) kepada Lasmini yang dibayarkan sebelum penandatanganan Akta Jual Beli.

Untuk pembayaran selanjutnya Sudiyana dan Lasmini sepakat bahwa pembayaran dilakukan melalui PT. Bank Pundi Indonesia, Tbk, Kantor Cabang Ahmad Yani, Bekasi, sebagaimana dituangkan dalam Akta Jual Beli dengan menitipkan sertipikat tanah dan bangunan di bank. Pada intinya Sudiyana mendapat fasilitas kredit rumah sebesar Rp. 350.000.000 (tiga ratus lima puluh juta rupiah) untuk melunasi pembayaran rumah tersebut kepada PT. Bank Pundi Indonesia, Tbk, Kantor Cabang Ahmad Yani, Bekasi.

Berdasarkan hal tersebut maka Sudiyana melakukan Pembayaran sebesar Rp. 350.000.000 (tiga ratus lima puluh juta rupiah) kepada Lasmini melalui PT. Bank Pundi Indonesia, Tbk, Kantor Cabang Ahmad Yani, Bekasi. Selatah Sudiyana melakukan kewajiban pembayaran kredit rumah melalui PT. Bank Pundi Indonesia dan melakukan pelunasan pembayaran kredit rumah tersebut sesuai dengan Surat Keterangan Lunas No. 003/SKL/BPD Bantenkcbekasi/III/17 tanggal 13 Maret 2017 dari Bank Pembangunan Daerah Banten Tbk, KC Bekasi yang menyatakan bahwa fasilitas kredit atas nama Lasmini, No. Loan 04000803, sebesar Rp. 237. 885.062,90 selama 73 bulan dinyatakan Telah Lunas.

Berdasarkan Akta Surat Kuasa yang dikeluarkan oleh Notaris Woedjoed Wiradi, SH. M.KN pada tanggal 11 November 2014, dinyatakan bahwa Lasmini memberikan kuasa kepada Sudiyana untuk mengambil dokumen dan sertipikat pada Bank Pundi, Tbk Kantor Cabang Ahmad Yani, Bekasi. Dengan demikian surat-surat dan dokumen dari bangunan dan tanah tersebut sudah menjadi hak milik Sudiyana sejak tanggal 13 Maret 2017.

Pada saat Sudiyana membeli rumah dan bangunan tersebut dari Lasmini, Lasmini menyampaikan bahwa rumah dan bangunan tersebut tidak dalam keadaan bermasalah atau bersengketa dengan pihak lain. Selain itu setelah Sudiyana membeli Tanah dan Bangunan dari Lasmini tidak pernah menjaminkan Sertipikat Guna Bangunan No. 1661/Jatiranggon kepada pihak lain. Namun ketika Sudiyana hendak melakukan proses balik nama atas Sertipikat Guna Bangunan No. 1661/Jatiranggon menjadi sertipikat hak milik ke Badan Pertanahan Nasional (BPN) pada tanggal 26 April 2017, Kepala Kantor Pertanahan Kota Bekasi BPN memberikan informasi bahwa Sertipikat Guna Bangunan No. 1661/Jatiranggon telah diblokir sejak 14 Maret 2016 yang diajukan oleh Lasmini.

Berdasarkan hal tersebut maka dapat diketahui bahwa pihak pembeli telah dirugikan oleh pihak penjual.Dimana pihak pembeli yang sudah beritikad baik membeli 
tanah dan bangunan serta telah melakukan pembayaran dengan lunas, namun pihak penjual melakukan pemblokiran terhadap sertipikat tanah dan bangunan tersebut tanpa sepengetahuan dari pihak penjual.

Menurut ketentuan Pasal 126 Peraturan Menteri Agraria/Kepala BPN No. 3 Tahun 1997 tentang ketentuan Pelaksanaan PP No. 24 Tahun 1997 tentang Pendaftaran Tanah syarat permohonan pencatatan dalam buku tanah atau pemblokiran sertipikat hak atas tanah yaitu (Mardani, 2016):

a. Adanya pihak yang akan mengajukan gugatan atas objek sertipikat tanah yang dilayangkan ke pengadilan

b. Pencatatan atau blokir tanah tersebut berlaku selama 30 (tiga puluh) hari; dan bahwa atas permohonan pencatatan atau blokir tanah tersebut dijalankan atas perintah Majelis Hakim yang memeriksa perkara tersebut;

Catatan mengenai blokir akan terhapus dengan sendirinya dalam waktu 30 hari kecuali apabila diikuti dengan putusan sita jaminan yang salinan resmi dan berita acara eksekusinya disampaikan kepada Kepala Kantor Pertanahan (Peraturan Menteri Agraria /Kepala BPN No. 3 Tahun 1997 tentang ketentuan Pelaksanaan PP No. 24 Tahun 1997 tentang Pendaftaran Tanah, Pasal 126).

Berdasarkan uraian Pasal 126 tersebut maka dapat diketahui bahwa pengajuan pemblokiran Sertipikat Guna Bangunan seharusnya diajukan terlebih dahulu dengan melayangkan gugatan melalui Pengadilan Negeri dan blokir sertipikat dijalankan berdasarkan perintah Majelis Hakim yang memeriksa perkara tersebut. Selain itu seharusnya pemblokiran tersebut berakhir setelah 30 (tiga puluh) hari.Namun dalam uraian kasus di atas pemblokiran tanah dan bangunan berlangsung lebih dari 30 (tiga puluh) hari, sehingga hal tersebut menimbulkan kerugian bagi pihak pembeli yang telah beritikad baik.

Selain itu pemblokiran sertipikat biasa dilakukan untuk menghindari si pembeli mengalihkan tanah tersebut kepada pihak lain si penjual dapat memblokir sertipikat tanah tersebut terlebih dahulu.Untuk memblokir sertipikat tanah tersebut, si pejual dapat mengajukan surat permohonan pemblokiran sertipikat tanah kepada Kepala Kantor Pertanahan setempat dengan menyertakan alasan-alasan melakukan pemblokiran, sebagai contoh tanah tersebut sedang dalam sengketa hukum. Maka dari itu, surat permohonan harus dilampiri dengan dokumen-dokumen yang relevan, seperti foto copy surat gugatan atau laporan polisi, guna meyakinkan kantor pertanahan bahwa tanah tersebut dalam sengketa.

Ketentuan Pasal 1338 ayat (3) BW, salah satu syarat yang harus dipenuhi dalam menerapkan asas kebebasan berkontrak, adalah itikad baik dari pihak yang membuat perjanjian. Itikad baik dalam tahap pelaksanaan perjanjian adalah kepatutan, yaitu suatu penilaian baik terhadap tindak tanduk suatu pihak dalam melaksanakan apa yang akan diperjanjikan (R. Subekti, 2010). Asas itikad baik dengan demikian mengandung pengertian, bahwa kebebasan suatu pihak dalam membuat perjanjian tidak dapat diwujudkan sekehendaknya tetapi dibatasi oleh itikad baiknya (Remy, 1993). 
Pasal 1320 KUHPerdata menyebutkan empat syarat sahnya suatu perjanjian, yaitu: sepakat, mereka yang mengikatkan dirinya, kecakapan untuk membuat suatu perikatan, suatu hal tertentu,suatu sebab yang halal (Gumanti, 2012).

Pasal 1454 KUHPerdata menyebutkan bila suatu tuntutan untuk pernyataan batalnya suatu perikatan tidak dibatasi dengan suatu ketentuan undang-undang khusus mengenai waktu yang lebih pendek, maka waktu itu adalah lima tahun. Maka berdasarkan kasus tersebut, hal ini ditemui di dalam praktek, perjanjian pengikatan jual beli tidak senantiasa mengalami perjalanan yang lancar. Hal ini dapat kita lihat, manakala timbul suatu perselisihan-perselisihan disertai sengketa di kantor pertanahan dan hingga yang diangkat di hadapan sidang pengadilan. Timbulnya perselisihan ini diakibatkan karena terjadinya tidak adanya asas itikad baik dari pihak penjual (Setiawan Rahmat, 2005).

Sementara itu, masalah jual beli tidak dapat dipisahkan dari kehidupan masyarakat sehari-hari dan itikad baik dalam jual beli merupakan faktor yang penting sehingga pembeli yang beritikad baik akan mendapat perlindungan hukum secara wajar menurut peraturan perundang-undangan yang berlaku,sedangkan yang tidak beritikad baik tidak perlu mendapat perlindungan hukum.

Oleh karenanya ada hal-hal yang harus diperhatikan dalam jual beli khususnya jual beli atas tanah, seperti status hukum tanah tersebut apakah sedang dalam sengketa atau tidak dan sedang dijaminkan atau tidak, hal tersebut biasanya tercantum dalam surat pernyataan tidak dalam sengketa yang ditandatangani oleh pihak penjual dan diketahui oleh pejabat daerah setempat dimana objek jual beli itu berada. Itikad baik yang ditunjukkan oleh pihak pembeli yaitu dengan membayar harga yang telah disepakati, dan pihak penjual berkewajiban menyerahkan objek jual beli yang telah dibayar kepada pihak pembeli dalam keadaan tidak sedang dijaminkan ke instansi manapun atau dilakukan jual beli terhadap pihak manapun.

Sehingga hal ini merupakan salah satu problem hukum apabila penjual tidak memiliki itikad baik yaitu tidak mengatakan yang sebenarnya mengenai obyek tanah yang dijualnya, seperti misalnya tanah sudah dilakukan jual beli kepada pihak lain tetapi tidak dikatakan secara terus terang atau tanah yang dijual sebenarnya masihdalam sengketa atau telah dilakukan pemblokiran terhadap sertipikat atas tanah tersebut. Selain itu, bila pembelian atau penjual tidak mempunyai itikad baik akan menyulitkan notaris untuk membuatkan akta jual beli tanahnya mengingat notaris kesulitan dalam menilai itikad baik dari para pihak baik penjual maupun pembeli.

Berkaitan dengan uraian tersebut diatas, apabila terjadi suatu peristiwa bahwa pihak penjual tidak memiliki itikad baik dalam transaksi jual beli tanah tersebut karena melakukan pemblokiran sertipikat tanah dan bangunan pada perjanjian jual beli tanah dan bangunan yang telah mengakibatkan kerugian-kerugian yang diderita oleh pihak pembeli yang beritikad baik maka pihak penjual berkewajiban untuk memberikan ganti kerugian kepada penggugat karena perbuatannya itu, hal tersebut sebagai bentuk kepastian hukum bagi pihak pembeli yang beritikad baik. Tujuan dari penelitian ini yaitu sebagai berikut: 1). Untuk mengetahui dan menganalisis prosedur pemblokiran 
sertipikat oleh pihak penjual dalam pelaksanaan perjanjian pengikatan jual beli tanah apabila pembeli wanprestasi. 2). Untuk mengetahui dan menganalisis kepastian hukum pemblokiran sertipikat oleh pihak penjual dalam pelaksanaan perjanjian pengikatan jual beli tanah yang dilakukan oleh penjual. 3). Untuk mengetahui dan menganalisis. 4). Perlindungan hukum terhadap pembeli yang beritikad baik atas pemblokiran sertipikat hak milik dalam pelaksanaan perjanjian pengikatan jual beli tanah. Suatu penelitian setidaknya harus mampu memberikan kegunaan baik teoritis maupun praktis dalam kehidupan masyarakat.Kegunaan penelitian ini dapat ditinjau dari dua segi yang saling berkaitan yaitudari segi teoritis dan segi praktis.

Hasil penelitian diharapkan bermanfaat bagi pengembangan keilmuan hukum khususnya hukum perdata dalam hal perjanjian pengikatan jual belihak atas tanah dan ilmu pengetahuan lainnya. Selain itu mampu memberi masukan bagi para pihak yang membutuhkan pengetahuan mengenai asas itikad baik dalam perjanjian pengikatan jual beli hak atas tanah. Serta sebagai bahan kajian awal yang lebih mendalam bagi penelitilainnya yang akan melakukan kajian atas asas itikad baik dalam perjanjian pengikatan jual beli hak atas tanah.

Memberikan masukan bagi para pihak yang terkait atau masyarakat dalam memaknai perlindungan hukum terhadap pembeli kedua yang beritikad baik atas pemblokiran sertipikat hak guna bangunan dalam pelaksanaan jual beli tanah. Selain itu dengan adanya penelitian ini diharapkan dapat menambah wawasan dan dapat memberikan informasi dalam memahami asas itikad baik dalam perjanjian pengikatan jual beli hak atas tanah.

\section{Metode Penelitian}

Penelitian ini menggunakan metode yuridis normatif yang selain itu juga didukung dengan menggunakan metode berpikir deduktif (cara berpikir dalam penarikan kesimpulan yang ditarik dari sesuatu yang sifatnya umum yang sudah dibuktikan bahwa dia benar dan kesimpulan itu ditujukan untuk sesuatu yang sifatnya khusus) (Sedarmayanti, 2017). Dengan demikian objek yang dianalisis dengan pendekatan yang bersifat kualitatif adalah metode penelitian yang mengacu pada normanorma hukum yang terdapat dalam peraturan perundang-undangan (Soerjono Soekanto, 2019).

\section{Hasil dan Pembahasan}

\section{A. Perlindungan Hukum Bagi Pihak Pembeli Dan Kreditur Atas Pemblokiran} Sertipikat Hak Milik Dalam Pelaksanaan Pengikatan Perjanjian Jual Beli Tanah

Perjanjian Pengikatan Jual Beli merupakan ikatan penjarjian pendahuluan yang dibuat antara penjual dan pembeli yang didasari atas kesepakatan sebelum jual beli dilaksanakan. Keinginan dan janji-janji dari penjual dan pembeli tersebut kemudian dituangkan dalam suatu akta perjanjian pengikatan jual beli, yang mana hal ini dilakukan untuk mengamankan kepentingan penjual dan pembeli serta bagaimana cara penyelesaiannya jika salah satu pihak melakukan wanprestasi. 
Akta Perjanjian Pengikatan Jual Beli ini dilakukan sebelum terjadinya peristiwa hukum jual beli dan dituangkan dalam Akta Jual Beli (AJB). Dengan demikian PPJB tidak dapat disamakan dengan AJB yang merupakan bukti pengalihan hak atas tanah/bangunan dari penjual kepada pembeli.

Namun, dengan dibuatkannya Perjanjian Pengikatan Jual Beli ini diharapkan secara yuridis dapat memberikan jaminan kepastian hukum dan hak bagi para pihak. Dalam penelitian ini penulis menemukan bahwa surat permohonan mengenai permohonan blokir buku tanah yang diajukan oleh penjual. Permohonan tersebut dilakukan oleh penjual ketika penjual masih menjadi nasabah dari salah satu bank yang memberikan pinjaman dengan mengagunkan sertifikat hak milik. Dan ketika penjual tanah dan bangunan tersebut menjual tanah dan bangunan tersebut, si penjual tidak mencabut blokir terlebih dahulu padahal pembelian mana dilakukan secara terang dan tunai. Bahwa memang, dalam Pasal 1458 KUH Perdata mengatakan: "jual beli telah terjadi antara kedua belah pihak, seketika setelah orangorang mencapai kata sepakat tentang benda dan harganya, walaupun benda itu belum diserahkan dan harganya belum dibayar." Kemudian dikatakan oleh Pasal 1459 KUH Perdata: "Hak milik atas barang yang dijual tidaklah berpindah kepada pembeli, selama penyerahannya belum dilakukan menurut Pasal 612, 613 dan 616 KUH Perdata”. Namun dengan adanya pasal tersebut bukan berarti penjual melalaikan kewajibannya untuk mencabut blokir sebagai syarat kepastian objek jual beli.

Selain itu juga, selaku penjual diwajibkan untuk menjaminkan penguasaan benda yang dijual secara aman dan tentram kepada pembeli dan adanya cacat-cacat barang tersembunyi sebagaimana tertera dalam Pasal 1491 KUH Perdata.

Cacat-cacat tersembunyi dalam hal ini ialah mengenai adanya kekurangan dari sertipikat dalam hal ini belum dilakukan pencabutan blokir atas sertifikat tersebut. Dengan melekatnya kewajiban penjual sebagaimana telah diatur dalam pasal tersebut, seharusnya kedudukan pembeli telah memiliki Hubungan hukum yang terjalin sebagai akibat perbuatan hukum jual beli dibentuk atas perjanjian atau persetujuan diantara pihak yang berkepentingan. Peranan kejujuran atau itikad baik sangat dibutuhkan dalam perjanjian, sehingga akan tercapai sesuai dengan kemauan serta perasaan hukum para pihak yang membuat perjanjian tersebut.

Apabila menunjuk kepada Pasal 125 ayat (2) dan 126 ayat (1) Peraturan Menteri Agraria/Kepala Badan Pertanahan Nasional Nomor 3 Tahun 1997 tentang Ketentuan Pelaksanaan Peraturan Pemerintah Nomor 24 Tahun 1997 tentang Pendaftaran Tanah, pencatatan/pemblokiran buku tanah sertipikat hanya dapat dilakukan oleh pihak yang berkepentingan dengan melampirkan salinan resmi penetapan/putusan pengadilan yang telah memperoleh kekuatan hukum tetap dan salinan Berita Acara Eksekusi atau melampirkan salinan surat gugatan atas suatu hak atas tanah yang akan dijadikan obyek di pengadilan.

Kenyataannya kantor pertanahan tetap mencatatkan blokir buku tanah atas sertipikat tersebut dengan hanya berdasarkan Akta Perjanjian Pengikatan Jual Beli 
yang telah dibuat dihadapan notaris sebagai salah satu alat bukti kepemilikan. Akta Perjanjian Pengikatan Jual Beli mengandung unsur sepakat antara pihak penjual dan pihak pembeli, maka dengan adanya kata sepakat ini lahirlah perikatan, namun hak milik atas objek perikatan yang tercantum di dalam Akta PPJB belum dapat dinyatakan beralih, untuk peralihan tersebut harus diadakan levering atau penyerahan. Penyerahan atau levering adalah merupakan tindakan atau perbuatan pemindahan hak kepemilikan atas sesuatu barang atau benda dari seseorang kepada orang lain. Namum perlu dipahami bahwa peralihan atau berpindahnya hak atas kekayaan dari seseorang kepada orang lain dapat terjadi dengan titel umum dan titel khusus. Oleh karena itu, dengan dibuatnya perjanjian pengikatan jual beli saja belum mengakibatkan beralihnya hak milik atas suatu benda dari penjual kepada pembeli. Tahapan ini baru merupakan kesepakatan (konsensual) dan harusdiikuti dengan perjanjian penyerahan (levering) (R. Subekti, 1987), yaitu di tandatanganinya akta jual beli dihadapan Pejabat Pembuat Akta Tanah untuk selanjutnya dilakukan pendaftaran haknya pada kantor pertanahan yang berwenang. Akta perjanjian pengikatan jual beli dalam permohonan pemblokiran bukan merupakan salah satu unsur untuk memenuhi permohonan pemblokiran oleh pihak yang berkepentingan dikabulkan oleh kantor pertanahan, PPJB hanyalah merupakan alat bukti telah terjadinya penyerahan secara nyata (feitelijke levering) dan penyerahan yuridis (yuridische levering) antara pihak penjual dan pihak pembeli atas objek jual beli untuk selanjutnya dimasukan ke dalam surat gugatan yang menjadi persyaratan administratif permohonan pemblokiran pada kantor pertanahan.

\section{Kesimpulan}

Akta Pengikatan Jual Beli yang dibuat dihadapan Notaris dalam pelaksanaannya sebagai perjanjian awal sebelum dilaksanakannya pembuatan akta jual beli, mempunyai kekuatan hukum yang sangat kuat, karena merupakan akta notariil yang bersifat akta otentik. Akta pengikatan jual beli sebagai sarana untuk mengikat keinginan para pihak yang berkepentingan dalam pembuatan akta jual beli namun masih terkendala dengan adanya kekurangan syarat-syarat administratif, dalam hal ini dengan akta pengikatan jual beli tersebut, tanah yang menjadi obyek jual beli telah dapat beralih dari penjual kepada pembeli.

Sedangkan Kuasa menjual merupakan bentuk perlindungan hukum bagi pembeli tanah Sertifkat Hak Milik berdasarkan akta pengikatan jual beli, yang tetap menganut makna dari Pasal 1818 KUHPerdata. Sertifikat Hak Milik merupakan suatu bukti yang kuat bagi pemilik tanah untuk mengalihkan hak atas tanahnya tersebut. Selanjutnya berdasarkan asas rehtverwerking, pihak yang merasa dirugikan atas terbitnya sertifikat tersebut apabila dalam jangka waktu 5 (lima) tahun tidak mengajukan tuntutan, maka tuntutan atau keberatan pihak yang dirugikan oleh terbitnya sertifikat tersebut dianggap gugur, hal tersebut termaksud dalam Peraturan Pemerintah Nomor 24 Tahun 1997 Pasal 32 Ayat 2. 


\section{BIBLIOGRAFI}

Dilapanga, Reynaldi A. (2017). Sertifikat Kepemilikan Hak Atas Tanah Merupakan Alat Bukti Otentik Menurut Undang-undang Pokok Agraria No. 5 Tahun 1960. Lex Crimen, 6(5). Google Scholar

Gumanti, Retna. (2012). Syarat Sahnya Perjanjian (Ditinjau dari KUHPerdata). Jurnal Pelangi Ilmu, 5(01). Google Scholar

Harsono, Boedi. (1999). Hukum Agraria Indonesia: Sejarah Pembentukan UUPA. Isi Dan Pelaksanaannya, Djambatan, Jakarta. Google Scholar

Mardani. (2016). Hukum Keluarga Islam di Indonesia. Jakarta: Kencana.

R. Subekti. (1987). Hukum Perjanjian. Bandung: Bina Cipta.

R. Subekti. (2010). Hukum Perjanjian. Jakarta: Jakarta: PT Intermasa.

Remy, Sjahdeini Sutan. (1993). Kebebasan Berkontrak dan Perlindungan yang seimbang bagi para pihak dalam perjanjian kredit bank di Indonesia. Jakarta, Institut Bank Indonesia. Google Scholar

Sedarmayanti. (2017). Manajemen Sumber Daya Manusia Reformasi Birokrasi dan Manajemen Pegawai Negeri Sipil. Bandung: PT Refika Aditama. Google Scholar

Setiawan Rahmat. (2005). Pokok-Pokok Hukum Perikatan. Bandung: Putra Abardin. Google Scholar

Soeikromo, Deasy. (2013). Pengalihan Hak Milik Atas Benda Melalui Perjanjian Jual Beli Menurut KUH Perdata. Jurnal Hukum Unsrat, 1(3), 89-97. Google Scholar

Soerjono Soekanto. (2019). Pengantar Penelitian Hukum. Jakarta: UI Press. Google Scholar

Supriadi. (2006). Cetakan kedua. In Sinar Grafika, Jakarta. Google Scholar

Sutedi, Adrian. (2008). Peralihan Hak Atas Tanah dan Pendaftarannya, cetakan kedua. Sinar Grafika, Jakarta. Google Scholar

\section{Copyright holder:}

Alit Nurfatah Prihadiansyah, Ariawan (2021)

First publication right:

Syntax Literate: Jurnal Ilmiah Indonesia

This article is licensed under:

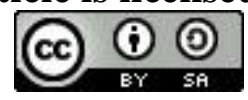

